Naturæ" was issued very early in the year 1758. For practical reasons, this date may be assumed to be January 1, 1758, and any other zoological publication bearing the date 1758 may be construed as having appeared subsequent to January 1. In so far as the date is concerned, all such publications may therefore be construed as entitled to consideration under the law of priority.

Status of Certain Names Published as Manuscript Names.-Manuscript names acquire standing in nomenclature when printed in connection with the provisions of Art. 25, and the question as to their validity is not influenced by the fact whether such names are accepted or rejected by the author responsible for their publication.

Status of Certain Pre-Linncean Names Reprinted Subsequent to 175\%.-A pre-Linnæan name, ineligible because of its publication prior to 1758 , does not become eligible simply by being cited or reprinted with its original diagnosis after 1757. To become eligible under the code, such names must be reinforced by adoption or acceptance by the author publishing the reprint. Examples: The citation, subsequent to 1757 , of a bibliographic reference to a paper published prior to 1758 does not establish technical names which may appear in said reference; synonymic citation of preLinnæan names, as in the tenth edition of Linné's "Systema Naturæ," does not establish such names under the code.

$$
\begin{array}{r}
\text { Ch. WARDell Strues, } \\
\text { Secretary }
\end{array}
$$

\section{WILBUR OLIN ATWATER}

As the outcome of an illness lasting nearly three years, Professor Wilbur Olin Atwater died at his home in Middletown, Conn., on the evening of September 22, 1907. Professor Atwater was born in Johnsburgh, N. Y., on May 3, 1844. After three years of undergraduate life as a student in the University of Vermont, he spent his senior year at Wesleyan University, graduating in $\mathbf{1 8 6 5 .}$ Several years were spent in teaching in high schools and he then devoted some time to the study of chemistry at the Sheffield Scientific
School, receiving the degree of Doctor of Philosophy from Yale University in 1869. His thesis dealt with the composition of several varieties of American maize, thus early showing his tendencies to agricultural science-tendencies that were stimulated by further study at foreign universities in Leipsic and Berlin.

On return from foreign study, he was successively called to professorships in the East Tẹnessee University, Maine State College, and Wesleyan University. Taking up his work at this latter institution in the then new Orange Judd Hall of Natural Sciences, he began to prosecute researches particularly in the field of agriculturàl chemistry, enlisting the cooperation of the farmers and awakening interest in the rapidly developing chemistry of fertilizers. This active interest in agricultural chemistry he retained until his death. Recognizing the great service to agricultural science resulting from the experiment stations in Germany, he founded at Wesleyan University the first American agricultural experiment station in $\mathbf{1 8 7 5}$. This station was subsequently removed to New Haven and is there continued as the Connecticut Agricultural Experiment Station. In 1888, the Storrs (Conn.) Agricultural Experiment Station was organized and Professor Atwater was appointed its director, a position he held until 1902.

The rapid development of the experiment station movement soon showed that some central clearing house was necessary to give the results of the various stations proper publicity, to promote cooperation among the various experiment station workers and to prevent as far as possible unnecessary duplication of work. To this end, the Office of Experiment Stations of the U. S. Department of Agriculture was created and Professor Atwater was appointed its first director.

It was a natural transition from the study of animal feeding to that of the feeding of man and soon Professor Atwater was directing his energies to chemical and statistical researches on the food and nutrition of man. His early experience as special agent of the U. S. Department of Labor developed in his 
mind to a high degree the importance of the social and economic study of the relations of food and diet to the labor power, health and moral tone of communities and the scientific studies of dietaries begun in a small way developed into a large investigation of the dietetic conditions obtaining in various parts of the United States. Special appropriations were secured from Congress to study the nutrition of man and the whole enterprise soon partook of the nature of an extensive cooperative study of food and diet. These studies were carried out with the active assistance of various investigators in numerous universities and colleges and they extended literally from Maine to California.

In company with his colleague, Dr. E. B. Rosa, he developed at Wesleyan University a respiration calorimeter for experiments with man, in which many researches into the fundamental laws of metabolism have been made. Perhaps the investigation of greatest theoretical interest is the series of experiments made with this apparatus demonstrating that the law of the conservation of energy obtained in the physiological transformations of the living body.

An investigation into the nutritive value of alcohol made with this apparatus by the aid of grants from the Committee of Fifty for the Investigation of Alcohol attracted much notice, both in America and in Europe, and Professor Atwater soon began an active campaign in the interest of rational temperance reform.

Professor Atwater was a member of a large number of scientific societies and kindred institutions. He was a foreign member of the Swedish Royal Academy of Agriculture and a corresponding member of the Russian Imperial Military Academy. His chemical, agricultural and economic writings have been translated into several foreign languages and few American scientists were better known abroad than was he. His writings number somewhat over 100 papers and cover a large field.

It was perhaps as an administrative officer and organizer that Professor Atwater rendered the greatest service to American science, and he will always be noted for the establishment of the experiment station movement. As the first director of the Office of Experiment Stations, he chose as his assistants Dr. A. W. Harris, now president of Northwestern University, who became his immediate successor, and Dr. A. C. True, now director of the Office of Experiment Stations. Thus, in large measure, the policy which he inaugurated has been continued from the creation of this office.

Of remarkable activity and energy, Professor Atwater attracted many young men to his laboratory and his loss will be especially felt by all those who have had the good fortune to have come under his influence during his active career as a director of research for more than thirty years.

F. G. B.

\section{SCIENTIFIC NOTES AND NEWS}

The memorial statue of Joseph Leidy, the eminent anatomist and zoologist, erected on the west side of the City Hall Plaza, Philadelphia, will be unveiled at 3 P.M. on Wednesday, October 30. Addresses will be made by Mr. Joseph Wharton and Professor Henry C. Chapman, M.D.

Dr. G. Hellmann has been appointed professor of meteorology in the University of Berlin and director of the Prussian Meteorological Service, in succession to the late Professor von Bezold.

ON the occasion of the recent celebration of the centenary of the Geological Society of London, the gold medal of the Institution of Mining and Metallurgy was presented to Sir Archibald Geikie, the president of the society.

President Hadlex, of Yale University, has sailed for Germany, to spend six months as Roosevelt professor of American history and institutions in the University of Berlin, on the Columbia University foundation.

Dr. Robert F. WeIr and Dr. Charles McBurney, professors of clinical surgery, have been made emeritus professors of surgery at the College of Physicians and Surgeons, Columbia University.

Dr. G. N. Stewart, professor of physiology at Western Reserve University, has leave of 